BNL-52595

Formal Report

\title{
Low Temperature Glasses for Hanford Tank Wastes
}

\author{
Annual Report
}

FY 1995

H. Cao, J.W. Adams and P.D. Kalb, Brookhaven National Laboratory

\section{BROOKHBVEN \\ NATIONAL LABORATORY}

June 1995

\author{
Environmental Sciences Department \\ Brookhaven National Laboratory \\ Brookhaven Science Associates \\ Upton, Long Island New York 11973
}

Under Contract No. DE-AC02-98CH10886 with the

UNITED STATES DEPARTMENT OF ENERGY 


\section{DISCLAIMER}

This report was prepared as an account of work sponsored by an agency of the United States Government. Neither the United State Government nor any agency thereof, nor any of their employees, not any of their contractors, subcontractors, or their employees, makes any warranty, express or implied, or assumes any legal liability or responsibility for the accuracy, completeness, or usefulness of any information, apparatus, product, or process disclosed, or represents that its use would not infringe privately owned rights. Reference herein to any specific commercial product, process, or service by trade name, trademark, manufacturer, or otherwise, does not necessarily constitute or imply its endorsement, recommendation, or favoring by the United States Government or any agency, contractor, or subcontractor thereof. The vies and opinions of authors expressed herein do not necessarily state or reflect those of the United States Government or any agency, contractor or subcontractor thereof.

Printed in the United States of America

Available from

National Technical Information Service

U.S. Department of Commerce

5285 Port Royal Road

Springfiled, VA 22161 


\title{
Low Temperature Glasses for Hanford Tank Wastes*
}

\author{
Annual Report \\ FY 1995 \\ H. Cao, J.W. Adams and P.D. Kalb, Brookhaven National Laboratory \\ June 1995
}

\begin{abstract}
$\underline{\text { Abstract }}$
TWRS wastes contain certain chemical components which, either because of their limited solubility or volatilization at high temperatures, present problems for conventional vitrification technologies. The current task completed by BNL concerns the use of low temperature glasses for tank waste remediation. A literature review of existing technologies highlighted lead-iron-phosphate glasses, with melt temperatures of around $900^{\circ} \mathrm{C}$, as a significant improvement over existing borosilicate formulations. However, concerns over leachability of the high lead levels in the glass matrix has kindled interest in the development of lead-free phosphate glasses.
\end{abstract}

As part of this current task, crucible studies were performed to scope the potential of advanced phosphate glasses. Based on pioneer work on iron-aluminum-phosphate and tin-phosphate glasses, new formulations were investigated, modified with cations to enhance chemical durability and reduce melt temperatures. Dissolution of matrix metals using a standard leach test, the Product Characterization Test (PCT), was the basis used to evaluate the new glasses.

Cursory results indicate that low-temperature glasses can indeed be prepared with melt temperatures between 450 and $900^{\circ} \mathrm{C}$. Durability of these glasses and composites compares favorably with lead-iron-phosphate glasses, and is an improvement over reference borosilicate formulations. The capacity to incorporate high percentages of sodium was demonstrated, however much wastespecific work will be required to further qualify and quantify treatability of tank waste components.

\section{$\underline{\text { Introduction }}$}

Vitrification has been selected for immobilization of high-level radioactive waste (HLW) because glass is highly stable, very durable and has the ability to incorporate a wide variety of chemical contaminants. Overviews have thoroughly documented the historical and scientific basis for this selection. $\left[{ }^{1},{ }^{2}\right] \quad$ However, requirements for storage and disposal of low-level radioactive (LLW) and mixed wastes differ from those for HLW. In addition, LLW and mixed waste contaminants and waste chemistries can vary from those typically found in HLW. Thus, evaluation of vitrification or immobilization of these wastes should consider these differences.

${ }^{*}$ This work was performed under the auspices of the U.S. Department of Energy. 
Most current research on vitrification of mixed waste has focused on borosilicate glass formulations originally developed for HLW. Although borosilicate glass has demonstrated good long-term chemical durability and is both thermally and physically stable, it requires relatively high process temperatures $\left(1200-1500^{\circ} \mathrm{C}\right)$ for effective encapsulation of waste. These high temperatures are a major drawback because volatilization of certain isotopes (e.g. ${ }^{99} \mathrm{Tc}$ and ${ }^{137} \mathrm{Cs}$ ) and heavy metals (e.g., $\mathrm{Pb}$ and $\mathrm{Cd}$ ) can occur, requiring the use of secondary treatment systems to capture and stabilize these off-gas contaminants. Further, borosilicate glass processing is incompatible with even minor amounts $(>1.5$ mole $\%)$ of $\mathrm{P}_{2} \mathrm{O}_{5}$ in a waste stream. $\left[{ }^{3},{ }^{4}\right]$ Insoluble phosphate phases form depending on the amount of $\mathrm{CaO}$ and rare earth oxides present. Similarly, wastes containing $>0.3$ mole $\% \mathrm{Cr}_{2} \mathrm{O}_{3}$, $>16$ mole $\% \mathrm{Al}_{2} \mathrm{O}_{3}$, or $>19$ mole $\% \mathrm{Fe}_{2} \mathrm{O}_{3}$ have been flagged as outside the borosilicate glass concentration envelope. $\left[{ }^{5},{ }^{6}\right]$ Alternative vitrification processes or products are desirable for improved treatment of these wastes.

Promising new low-temperature glasses and glass-ceramics have been proposed based on advanced phosphate formulations. Current-year work has sought to provide a detailed assessment of phosphate glass technology. Alternative glass compositions were proposed, based on reducing melt temperatures, improving durability, or providing compatibility with specific waste stream components. Network modifiers have been adjusted to increase waste form durability while maintaining the advantage of low melting temperature. Unlike silicate glasses, whose durability is compromised by addition of modifying cations, corrosion resistance of some phosphate glasses can be enhanced with the addition of selected cations. High concentrations of $\mathrm{P}_{2} \mathrm{O}_{5}$ in certain wastes make phosphate glasses natural candidates for waste immobilization.

\section{Literature Review of Phosphate Glasses and Glass-Ceramics}

The chronology of phosphate glass development should not proceed without a basic understanding of the chemistry and structure of these materials. Sales has given a brief, but descriptive tutorial of the structural changes which occur in phosphate glasses with addition of metals. [ [] Pure $\mathrm{P}_{2} \mathrm{O}_{5}$ is characterized by a random three-dimensional network of $\mathrm{PO}_{4}$ tetrahedra: one oxygen atom is doubly bonded while the other three oxygen atoms bond to other tetrahedra. Pure $\mathrm{P}_{2} \mathrm{O}_{5}$ is extremely unstable and reacts violently with water to form $\mathrm{H}_{3} \mathrm{PO}_{4}$. Metals added to the glass break up the $\mathrm{PO}_{4}$ network as oxygen atoms preferentially bond to these metals. The structure of the network changes from a random arrangement of interconnecting $\mathrm{PO}_{4}$ tetrahedra to long chains of crosslinked $\mathrm{PO}_{4}$ tetrahedra, a structure more similar to organic polymers. With increasing metal concentrations, the chains depolymerize, becoming shorter and shorter until finally the vitreous nature of the material gives way to formation of more stable crystalline phases. While metal additions initially improve stability of the structure, their increased concentration decreases melt viscosity, increasing potential for crystal formation (devitrification). Indeed, the requirement for rapid cooling was also noted as a drawback to early efforts pursuing phosphate glasses as final waste forms.

Two-component (binary) phosphate glass systems, while of scientific curiosity, have found little commercial applicability due to their rapid degradation in water. The degree of attack is so severe that exposure to even normal ambient conditions cannot be considered. However, an 
understanding of physical and chemical behavior of these systems is useful in evaluating performance of more complicated glasses.

Early work to develop phosphate glass as a nuclear waste form was pioneered at Brookhaven National Laboratory (BNL) under contract to the U.S. Atomic Energy Commission, beginning in the late 1950's and continuing through the late 1960's. $\left[{ }^{8}\right]$ Work at BNL was targeted at development of a continuous glass-melting process for the treatment of Purex-type wastes, nitric acid solutions of the fission products and residual salts from the extraction of uranium and plutonium, together with corrosion products. Development of the BNL process was carried out through pilot-scale testing using simulated waste solutions. A plant-scale demonstration using actual Purex HLW was conducted during the mid to late 1960's as part of the Waste Solidification Engineering Prototypes (WSEP) program at the Pacific Northwest Laboratory (PNL). $\left[{ }^{9}\right]$

Aqueous Purex wastes were evaporated, forming primarily nitrate salts of $\mathrm{Fe}, \mathrm{Na}, \mathrm{Al}, \mathrm{Cr}$, and Ni. $\mathrm{SiO}_{2}, \mathrm{SO}_{4}$, and $\mathrm{PO}_{4}$ anions were also present in the waste, along with fission products, nominally in the concentration range of $10^{-3} \mathrm{M}$. Good glass formation was reportedly observed at $\mathrm{P}_{2} \mathrm{O}_{5}$ compositions greater than $65 \mathrm{~mol} \%$, for the $\mathrm{Fe}_{2} \mathrm{O}_{3}-\mathrm{Na}_{2} \mathrm{O}-\mathrm{P}_{2} \mathrm{O}_{5}$ ternary system, and at greater than 70 mol\% for the $\mathrm{Fe}_{2} \mathrm{O}_{3}-\mathrm{Al}_{2} \mathrm{O}_{3}-\mathrm{Na}_{2} \mathrm{O}-\mathrm{P}_{2} \mathrm{O}_{5}$ quaternary system. For the $\mathrm{Fe}_{2} \mathrm{O}_{3}-\mathrm{Na}_{2} \mathrm{O}-\mathrm{P}_{2} \mathrm{O}_{5}$ system, all glasses with less than 60 mol\% $\mathrm{P}_{2} \mathrm{O}_{5}$ devitrified. For the $\mathrm{Fe}_{2} \mathrm{O}_{3}-\mathrm{Al}_{2} \mathrm{O}_{3}-\mathrm{Na}_{2} \mathrm{O}-\mathrm{P}_{2} \mathrm{O}_{5}$ system, all glasses below $70 \mathrm{~mol} \%$ devitrified. Chemical durability of these glasses was not assessed.

Glass formulations were melted at $1100-1200^{\circ} \mathrm{C}$, with temperatures reduced to $800-900^{\circ} \mathrm{C}$ during idling periods to prevent volatilization of phosphate. Metal ions were typically retained at $>99.9 \%$ of their original amounts. Exceptions were ruthenium (94-99\%) and cerium (99\%), which appeared in the off-gas condensate, which was mainly $\mathrm{H}_{2} \mathrm{SO}_{4}$. The melt vessel was constructed of Inconel 702 with a Pt liner. Corrosion of the Pt liner was not a problem, although cracks did develop on several occasions, corroding the container. Inconel in contact with the molten phosphate reacted to form elemental phosphorus which, in turn, combined with the Pt to form alloys with lower melting points.

Phosphate glasses continued to be investigated in Europe, despite curtailment of research in the US. Sodium-aluminum phosphate glasses were investigated as part of the development of the West German PAMELA (phosphate glass solidification and metal embedding of liquid active waste) process. $\left.{ }^{10}\right]$ Glass melting was done at about $1100^{\circ} \mathrm{C}$ using a refractory lined melter with a liquid waste feed. Glasses were prepared as small beads to avoid devitrification problems. Low-alkali or alkali-free iron-aluminum phosphate glasses were found to have improved chemical durability, even lower than that of borosilicate glasses. $\left[{ }^{11}\right]$ Soxhlet (dynamic) leachabilities were found to be about $5 \times 10^{-5} \mathrm{~g} / \mathrm{cm}^{2} / \mathrm{d}$, although at temperatures above $100^{\circ} \mathrm{C}$, leachability increased rapidly. $\left[{ }^{12}\right]$ Glasses were nominally $5 \mathrm{wt} \% \mathrm{Al}_{2} \mathrm{O}_{3}, 15 \mathrm{wt} \% \mathrm{Fe}_{2} \mathrm{O}_{3}$, and $50 \mathrm{wt} \% \mathrm{P}_{2} \mathrm{O}_{5}$, containing about $30 \mathrm{wt} \%$ waste oxides.

Lead-iron phosphate (LIP) glass nuclear waste forms were introduced and characterized in detail by Sales and Boatner in the mid 1980's. $\left[{ }^{13},{ }^{14}\right]$ While lead phosphate glasses had been studied since the mid 1950's, their poor durability in water made them of little commercial interest. Vitrified waste forms containing iron oxide, however, were found to fare favorably compared with borosilicate glass waste forms, rekindling new interest in phosphate glass waste materials. LIP glasses could be 
processed at temperatures $100-250^{\circ} \mathrm{C}$ lower than borosilicate glasses using glass melting technology similar to that developed for borosilicate glasses. Solidified forms had dissolution rates in water about 1000 times lower than comparable borosilicate formulations, at $90^{\circ} \mathrm{C}$ in solutions with a $\mathrm{pH}$ between 5 and 9.

The addition of iron to lead phosphate glass was found to dramatically increase chemical durability of the glass, by a factor of about $10^{4}$ for a $9 \mathrm{wt} \%$ iron oxide addition. Also, the tendency for the glass to crystallize on cooling (or reheating) was greatly suppressed. Without the iron modifier, lead metaphosphate glasses completely crystallized in air at $300^{\circ} \mathrm{C}$ within a few hours. In contrast, LIP glasses were heated for several hundred hours at $500^{\circ} \mathrm{C}$ without any signs of devitrification. A variety of metal oxide modifiers were investigated for similar effects $\left(\mathrm{MgO}, \mathrm{Al}_{2} \mathrm{O}_{3}\right.$, $\mathrm{CaO}, \mathrm{Sc}_{2} \mathrm{O}_{3}, \mathrm{TiO}_{2}, \mathrm{VO}_{2}, \mathrm{Cr}_{2} \mathrm{O}_{3}, \mathrm{MnO}_{2}, \mathrm{CoO}, \mathrm{NiO}, \mathrm{Cu}_{2} \mathrm{O}, \mathrm{ZnO}, \mathrm{Ga}_{2} \mathrm{O}_{3}, \mathrm{Y}_{2} \mathrm{O}_{3}, \mathrm{ZrO}_{2}, \mathrm{In}_{2} \mathrm{O}_{3}, \mathrm{La}_{2} \mathrm{O}_{3}$, $\mathrm{CeO}_{2}$, and $\mathrm{Gd}_{2} \mathrm{O}_{3}$ ), although none were as effective. Compositional ranges for the three major components were: $\mathrm{PbO}$ (37-60 wt \%), $\mathrm{Fe}_{2} \mathrm{O}_{3}$ (6-13 wt \%), and $\mathrm{P}_{2} \mathrm{O}_{5}$ (32-44 wt \%), where waste loadings ranged from 14-19 wt $\%$. Practical concentration ranges for glass matrix formation were given to be: $\mathrm{PbO}(40-66 \mathrm{wt} \%), \mathrm{Fe}_{2} \mathrm{O}_{3}(0-12 \mathrm{wt} \%)$, and $\mathrm{P}_{2} \mathrm{O}_{5}(30-60 \mathrm{wt} \%)$. Glasses were melted at temperatures between 900 and $1050^{\circ} \mathrm{C}$.

Structure of LIP glass was characterized extensively, using Mossbauer spectroscopy, electron paramagnetic resonance, Raman and infrared spectroscopy, EXAFS (Extended X-ray Absorption Fine Structure), low-angle X-ray scattering, liquid chromatography, and transmission electron microscopy. $\left[{ }^{15},{ }^{16}\right]$ For glasses prepared below $900^{\circ} \mathrm{C}$, iron was incorporated in the glass as $\mathrm{Fe}^{+3}$. Average polyphosphate chain length was reduced from $>15$ for iron-free glasses, to about 2.6 for glass with $9 \mathrm{wt} \% \mathrm{Fe}_{2} \mathrm{O}_{3}$. Thus the improvement in durability was related to strengthened cross bonding between polyphosphate chains.

PNL conducted an evaluation of LIP glasses as part of the Second Generation HLW Technology Subtask of the Nuclear Waste Treatment Program. $\left[{ }^{17}\right]$ Their review found LIP glasses to have substantially better chemical durability than borosilicate glass, although severe devitrification (leading to reduced chemical durability) would result if glass waste forms were prepared in large canisters. Cooling requirements have been subsequently addressed and solved, for example, by bubbling gas through the melt prior to the pour so as to completely avoid devitrification. $\left[{ }^{18}\right]$ LIP glasses were similarly examined for their potential applicability for Savannah River Plant (SRP) waste. $\left[{ }^{19}\right]$ Phosphate glasses were found to be highly durable, however, the glass melts were considered highly corrosive with existing glass melting equipment. Thermal stability and waste component solubility were lower than for high-silica glasses. Thus, borosilicate glasses were found to be, overall, more favorable for SRP waste treatment.

Ultra low melting temperature lead-tin fluorophosphate glasses were investigated by Tick, showing glass transition temperatures of $75-150^{\circ} \mathrm{C}$ with good resistance to water attack. $\left[{ }^{20}\right]$ Reported compositional ranges investigated were 50-61 atomic percent (at\%) Sn, 3.0-5.7 at\% $\mathrm{Pb}$, and 34-48 at\% P, with fluorine and oxygen contents of 35-74 and 114-149 atoms per 100 cations, respectively. Glass melting was done in air at $450^{\circ} \mathrm{C}$. Although lead additions had little effect on glass transition temperature, lead-tin phosphate glasses were readily devitrified without lead as glass component, suggesting that lead has a significant effect on the bonding character in the glass. With regards to chemical durability, four distinct corrosion behaviors were noted for the glass formulations 
tested, corresponding to very high $\left(>10 \mathrm{mg} / \mathrm{cm}^{2}\right.$ day) to relatively low $\left(<0.1 \mathrm{mg} / \mathrm{cm}^{2}\right.$ day) dissolution rates. Best durability was associated with the compositional window defined by $8<\mathrm{Sn} / \mathrm{Pb}<13$ and $1<\mathrm{Sn} / \mathrm{P}<2$, with $\mathrm{F} / \mathrm{Sn}=1 \pm 0.2$. Outside this region, phase separation was suspected, producing swelling or accelerated dissolution. There are no reports about their chemical stability in acid or basic solutions so far.

Few recent advances in phosphate glass waste forms have been reported as current interest seems to be focused on phosphate glass laser development and associated optical and electronic characterization. Structure models continue to be updated, using high performance liquid chromatography and x-ray spectrometry to analyze glass samples. $\left[{ }^{21},{ }^{22}\right]$ Chemical durability improvements in alkali phosphate glasses were proposed in a patent application by Day and Wilder.[ $\left.{ }^{23}\right]$ Glasses containing 10-60 mole $\%$ of $\mathrm{Li}_{2} \mathrm{O}, \mathrm{Na}_{2} \mathrm{O}$, or $\mathrm{K}_{2} \mathrm{O} ; 5-40$ mole $\%$ of $\mathrm{BaO}$ or $\mathrm{CaO}$; 0-10 mole $\%$ of $\mathrm{Al}_{2} \mathrm{O}_{3}$; and 40-70 mole $\%$ of $\mathrm{P}_{2} \mathrm{O}_{5}$ were improved by incorporating up to $23 \mathrm{wt} \%$ of nitrogen. Nitrides were the favored additives.

Certain glass-ceramics or glass-composites may possess higher chemical durabilities than single phase glasses with respect to dissolution in water or corrosion resistance in harsh environments. Glass-ceramics or glass-composites may be formulated on devitrification, consisting of a major, thermodynamically stable crystalline phase and a relatively durable, vitreous matrix. They are important candidates for nuclear waste immobilization.

Various combinations of phosphate glass-ceramic matrices have been manufactured at the research level. For example, new castable glass-ceramic dental materials have the potential for use in many phases of restorative dentistry, and much work has been carried out by Corning Glass Works on glass-ceramics based on crystallization of the parent glass. $\left[{ }^{24},{ }^{25}\right]$ Bio-compatible calcium phosphate glass-ceramics were developed in Japan, possessing extremely high toughness and flexibility. These new materials were claimed to be durable in both acid and alkaline solutions. $\left[{ }^{26}\right]$ In Canada, glass-ceramics based on partial crystallization of precursor glasses from the system $\mathrm{Na}_{2} \mathrm{O}$ $\mathrm{Al}_{2} \mathrm{O}_{3}-\mathrm{CaO}-\mathrm{TiO}_{2}-\mathrm{SiO}_{2}-\mathrm{X}$ (where $\mathrm{X}$ are the waste oxides or the minor processing additives) were developed for the possible solidification of fuel recycle waste. $\left[{ }^{27}\right]$ Fabrication temperatures of $<1200^{\circ} \mathrm{C}$ and pressures around 20-37 MPa were used. Similar results were obtained in the U.S. for $\mathrm{R}_{2} \mathrm{O}-\mathrm{RO}-\mathrm{P}_{2} \mathrm{O}_{5}$ and $\mathrm{R}_{2} \mathrm{O}-\mathrm{Al}_{2} \mathrm{O}_{3}-\mathrm{P}_{2} \mathrm{O}_{5}$ glasses (where alkali metals are $\mathrm{Na}$ or $\mathrm{Li}$, and alkaline earth metals are $\mathrm{Ca}$ or $\mathrm{Ba}$ ) doped with $1 \mathrm{~mol} \%$ of $\mathrm{TiO}_{2}, \mathrm{ZrO}_{2}, \mathrm{Y}_{2} \mathrm{O}_{3}, \mathrm{La}_{2} \mathrm{O}_{3}$, or $\mathrm{Ta}_{2} \mathrm{O}_{5}$. $\left[{ }^{28}\right]$ Glass-ceramics from the system $\mathrm{SiO}_{2}-\mathrm{Cs}_{2} \mathrm{O}-\mathrm{Al}_{2} \mathrm{O}_{3}-(\mathrm{La}, \mathrm{Ce})_{2} \mathrm{O}_{3}-\mathrm{P}_{2} \mathrm{O}_{5}-\mathrm{Zr}$ were developed for high level waste immobilization at processing temperatures of $\leq 1600^{\circ} \mathrm{C} .\left[^{29}\right]$ While these glass-ceramics exhibit good chemical durabilities, high melting temperatures and associated losses of volatile fission products from the melts would restrict potential use of these materials.

\section{Crucible Studies: Procedures and Results}

Crucible studies were conducted to verify literature results and to provide performance indicators for development of new glass-waste formulations. Work concentrated on preparation and characterization of advanced phosphate glass formulations. Two families of phosphate glasses were prepared; one based on the iron $(\mathrm{Fe})$-aluminum $(\mathrm{Al})$-phosphate $\left(\mathrm{P}_{2} \mathrm{O}_{5}\right)$ system, the other based on the tin (Sn)-phosphate system. Modifying cations were added to each glass in attempts to improve chemical durability, stability, and/or processability of the glass matrices. Oxides of lithium (Li), 
sodium $(\mathrm{Na})$, potassium $(\mathrm{K})$, calcium $(\mathrm{Ca})$, magnesium $(\mathrm{Mg})$ and boron $(\mathrm{B})$ were added or substituted in varying proportions to the base $\mathrm{Fe}_{2} \mathrm{O}_{3}-\mathrm{Al}_{2} \mathrm{O}_{3}-\mathrm{P}_{2} \mathrm{O}_{5}$ glass. Silicon ( $\mathrm{Si}$ ), $\mathrm{Na}, \mathrm{K}, \mathrm{Fe}$, and $\mathrm{Al}$ were used to modify $\mathrm{Sn}-\mathrm{P}_{2} \mathrm{O}_{5}$ glasses. A total of ten formulations were synthesized; eight $\mathrm{Fe}_{2} \mathrm{O}_{3}-\mathrm{Al}_{2} \mathrm{O}_{3}-\mathrm{P}_{2} \mathrm{O}_{5}$ glasses and two $\mathrm{Sn}-\mathrm{P}_{2} \mathrm{O}_{5}$ glass composites, as per the Fiscal Year Work Plan. In addition, x-ray diffraction analysis (XRD) and scanning electron microscopy (SEM) were used to analyze the glass or glass-ceramic nature of the resultant materials. Supplemental leaching at elevated temperature $\left(90^{\circ} \mathrm{C}\right)$ was also conducted to provide a more direct comparison with previous glass leaching data. Baseline glass performance was evaluated at ambient temperature using the Product Consistency Test (PCT) $\left[{ }^{30}\right]$, a standard glass leach test developed by Westinghouse Savannah River Co., presently submitted as ASTM Standard C26.13.

Glasses were prepared in small (20-50 g) batches of reagent-grade oxide powders. Raw chemicals were premixed in a rotating ball mill, then charged to $50 \mathrm{cc}$ porcelain crucibles. Melting was done in a laboratory convection oven under atmospheric conditions. Iron-aluminum-phosphate glasses were melted at a temperature of $900^{\circ} \mathrm{C}$ for $2-4$ hours, while tin-phosphate glasses were melted at $450^{\circ} \mathrm{C}$ for $1-2$ hours. Molten glasses were cast in stainless steel molds and allowed to cool to room temperature. The glass buttons were for the most part clear with few seeds (air bubbles). Samples were not stirred during melting and no attempt was made to measure viscosity of the melts. Colors ranged from light to dark brown for the iron-aluminum-phosphate glasses, as shown in Figure 1. Samples annealed at $150^{\circ} \mathrm{C}$ for up to 1 month showed no evidence of devitrification.

Tin-phosphate glass composites containing additives were also prepared to determine capabilities of the low temperature glass as an encapsulation medium. Resultant glass-ceramics, shown in Figure 2, are light to dark gray in color and similar in appearance to glassy slags. Figures 3 and 4 show XRD patterns typical of the glass and glass-ceramic materials synthesized. While matrix glass XRD patterns are representative of amorphous materials, those from the powdered tinphosphate glass composite indicate the presence of the crystalline waste bonded or encapsulated within the glass matrix.

Glass samples were comminuted to the -100 to +200 mesh size range specified for PCT. Large pieces were crushed inside a polyethylene bag by carefully striking with a hammer. Fines were further ground using a porcelain mortar and pestle. Powders were sieved through new 8-inch stainless steel sieves. Screens were cleaned and dried between batches, as per the test method, to prevent cross contamination of the glasses. Density of glass samples was measured using a Quantachrome pycnometer. Samples were measured both as chunks or buttons, and also as crushed glass powders. Using the equation in Appendix I of the PCT Test Method, surface areas for each glass were then calculated.

PCT testing was done using the requisite Teflon PFA (Perfluoralkoxy) vessels. Due to the fact that the intended use for these glass hosts is 'mixed' rather than 'high-level' waste, baseline leach tests were conducted at ambient temperature under the proviso of Test Method 'B', rather than at $90^{\circ} \mathrm{C}$ as specified by Method 'A', for high level waste forms. (The higher temperature test seeks to simulate the self-heating effect of vitrified high-level radioactive waste.) Two $90^{\circ} \mathrm{C}$ leach tests were conducted on iron-aluminum-phosphate glasses, however, to attempt to validate comparison of this data with baseline borosilicate leach test results (the bulk of this data is $90^{\circ} \mathrm{C} \mathrm{PCT} \mathrm{data).} \mathrm{Tests} \mathrm{were} \mathrm{done} \mathrm{using}$ purified (ASTM Type I) water in a volume 10 times the mass of the glass sample, for a period of 7 
days. Weights of glass samples tested ranged from 0.38 to $1.17 \mathrm{~g}$. All tests were done in triplicate. On completion of the leach test, leachates were analyzed by inductively coupled plasma (ICP) spectroscopy for matrix cations. Chemistry of the parent glasses were determined by totally digesting reference glasses in aqua regia and $\mathrm{HCl}$, and again analyzing by ICP for matrix components.

Leach rates of the dissolved metals were calculated as mass of metal leached (per gram of glass sample) divided by surface area (per gram of glass) and leach time. Data were normalized by dividing by the original amount of each element present in the glass, as determined by digestion of the parent glass. Leach data for Fe-Al- $\mathrm{P}_{2} \mathrm{O}_{5}$ glasses are shown in Table 1. Leach data for tinphosphate glass-composites are shown in Table 2. Standard deviations of the three replicate tests, typically an order of magnitude lower, are given below each value in parenthesis. Note that sample ID's were assigned in chronological order and are not representative of compositional trends or similarities. Samples BNL-5, 8, 9, and 13 are similar in that the glasses each contain $\mathrm{Na}_{2} \mathrm{O}-\mathrm{Li}_{2} \mathrm{O}-\mathrm{CaO}-$ $\mathrm{MgO}-\mathrm{Fe}_{2} \mathrm{O}_{3}-\mathrm{Al}_{2} \mathrm{O}_{3}-\mathrm{P}_{2} \mathrm{O}_{5}$. Samples BNL-10, 11, and 14 each contain $\mathrm{K}_{2} \mathrm{O}-\mathrm{Li}{ }_{2} \mathrm{O}-\mathrm{CaO}-\mathrm{MgO}-\mathrm{Fe}_{2} \mathrm{O}_{3}-$ $\mathrm{Al}_{2} \mathrm{O}_{3}-\mathrm{P}_{2} \mathrm{O}_{5}$, while BNL-7 contains $\mathrm{B}_{2} \mathrm{O}_{3}$ in addition to these. Samples BNL-6 and 12 contain $\mathrm{Na}(\mathrm{K})_{2} \mathrm{O}-\mathrm{SiO}_{2}-\mathrm{Fe}_{2} \mathrm{O}_{3}-\mathrm{Al}_{2} \mathrm{O}_{3}-\mathrm{SnO}-\mathrm{P}_{2} \mathrm{O}_{5}$. Data in the tables were arranged with increasing modifier content, although specific formulation details have been withheld pending patent applicability. Leach test blanks (containing no glass sample) were included with each series of tests. Blanks showed no detectable metals present after the 7 day period.

SEM microscopy was done on post-leach test glass powders to look for evidence of corrosion. As shown in Figures 5 and 6, leached samples were indistinguishable from untested samples. 
Table 1. PCT Leach Results for $\mathrm{Fe}_{2} \mathrm{O}_{3}-\mathrm{Al}_{2} \mathrm{O}_{3}-\mathrm{P}_{2} \mathrm{O}_{5}$ Glasses.

\begin{tabular}{|c|c|c|c|c|c|c|c|c|c|}
\hline \multicolumn{10}{|c|}{ Normalized Leach Rate, $\mathrm{g} / \mathrm{m}^{2} / \mathrm{d}^{\mathrm{a}}$} \\
\hline & $\mathrm{Li}$ & $\mathrm{Na}$ & K & $\mathrm{Mg}$ & $\mathrm{Ca}$ & $\mathrm{Fe}$ & B & $\mathrm{Al}$ & $\mathrm{P}$ \\
\hline BNL-10 & $\begin{array}{c}1.74 \mathrm{E}-02 \\
(9.92 \mathrm{E}-05) \\
\end{array}$ & $\mathrm{NA}^{\mathrm{b}}$ & $\begin{array}{c}1.72 \mathrm{E}-02 \\
(1.98 \mathrm{E}-04) \\
\end{array}$ & $\begin{array}{c}1.71 \mathrm{E}-02 \\
(3.73 \mathrm{E}-04) \\
\end{array}$ & $\begin{array}{c}1.41 \mathrm{E}-02 \\
(1.88 \mathrm{E}-04) \\
\end{array}$ & $\begin{array}{c}1.25 \mathrm{E}-02 \\
(8.09 \mathrm{E}-05) \\
\end{array}$ & NA & $\begin{array}{c}2.02 \mathrm{E}-02 \\
(2.34 \mathrm{E}-04) \\
\end{array}$ & $\begin{array}{c}1.69 \mathrm{E}-02 \\
(1.65 \mathrm{E}-04) \\
\end{array}$ \\
\hline BNL-11 & $\begin{array}{c}1.88 \mathrm{E}-02 \\
(6.41 \mathrm{E}-04) \\
\end{array}$ & NA & $\begin{array}{c}1.77 \mathrm{E}-02 \\
(8.35 \mathrm{E}-04) \\
\end{array}$ & $\begin{array}{c}1.69 \mathrm{E}-02 \\
(3.84 \mathrm{E}-04) \\
\end{array}$ & $\begin{array}{c}1.18 \mathrm{E}-02 \\
(1.16 \mathrm{E}-03) \\
\end{array}$ & $\begin{array}{c}1.18 \mathrm{E}-02 \\
(5.11 \mathrm{E}-04) \\
\end{array}$ & NA & $\begin{array}{c}1.49 \mathrm{E}-02 \\
(5.67 \mathrm{E}-04) \\
\end{array}$ & $\begin{array}{c}1.68 \mathrm{E}-02 \\
(3.02 \mathrm{E}-04) \\
\end{array}$ \\
\hline BNL-14 & $\begin{array}{c}4.38 \mathrm{E}-02 \\
(8.44 \mathrm{E}-04) \\
\end{array}$ & NA & $\begin{array}{c}3.08 \mathrm{E}-02 \\
(1.14 \mathrm{E}-03) \\
\end{array}$ & $\begin{array}{c}9.04 \mathrm{E}-03 \\
(5.89 \mathrm{E}-04) \\
\end{array}$ & $\begin{array}{c}1.30 \mathrm{E}-03 \\
(3.42 \mathrm{E}-04) \\
\end{array}$ & $\begin{array}{c}1.07 \mathrm{E}-03 \\
(1.83 \mathrm{E}-05) \\
\end{array}$ & NA & $\begin{array}{c}1.45 \mathrm{E}-03 \\
(7.45 \mathrm{E}-05) \\
\end{array}$ & $\begin{array}{c}2.16 \mathrm{E}-02 \\
(1.09 \mathrm{E}-04) \\
\end{array}$ \\
\hline BNL-8 & \begin{tabular}{|c|}
$8.43 \mathrm{E}-02$ \\
$(3.83 \mathrm{E}-03)$ \\
\end{tabular} & $\begin{array}{r}8.36 \mathrm{E}-02 \\
(4.97 \mathrm{E}-03) \\
\end{array}$ & NA & \begin{tabular}{|c|}
$8.07 \mathrm{E}-02$ \\
$(5.89 \mathrm{E}-03)$ \\
\end{tabular} & \begin{tabular}{|c|}
$9.64 \mathrm{E}-01$ \\
$(4.34 \mathrm{E}-01)$ \\
\end{tabular} & \begin{tabular}{|c|}
$8.40 \mathrm{E}-02$ \\
$(3.48 \mathrm{E}-03)$ \\
\end{tabular} & NA & \begin{tabular}{|c|}
$5.56 \mathrm{E}-02$ \\
$(3.97 \mathrm{E}-02)$ \\
\end{tabular} & \begin{tabular}{|c|}
$8.74 \mathrm{E}-02$ \\
$(3.34 \mathrm{E}-03)$ \\
\end{tabular} \\
\hline BNL-9 & $\begin{array}{c}2.15 \mathrm{E}-02 \\
(2.53 \mathrm{E}-04) \\
\end{array}$ & $\begin{array}{c}2.20 \mathrm{E}-02 \\
(4.37 \mathrm{E}-04) \\
\end{array}$ & NA & $\begin{array}{c}2.16 \mathrm{E}-02 \\
(3.28 \mathrm{E}-04) \\
\end{array}$ & $\begin{array}{r}1.79 \mathrm{E}-02 \\
(1.08 \mathrm{E}-03) \\
\end{array}$ & $\begin{array}{c}2.07 \mathrm{E}-02 \\
(3.64 \mathrm{E}-04) \\
\end{array}$ & NA & $\begin{array}{c}2.41 \mathrm{E}-02 \\
(5.60 \mathrm{E}-04) \\
\end{array}$ & $\begin{array}{c}2.23 \mathrm{E}-02 \\
(7.29 \mathrm{E}-04) \\
\end{array}$ \\
\hline BNL-5 & $\begin{array}{c}8.25 \mathrm{E}-03 \\
(1.27 \mathrm{E}-04) \\
\end{array}$ & $\begin{array}{r}6.93 \mathrm{E}-03 \\
(3.50 \mathrm{E}-04) \\
\end{array}$ & NA & $\begin{array}{c}2.62 \mathrm{E}-03 \\
(1.28 \mathrm{E}-04) \\
\end{array}$ & $\begin{array}{r}9.35 \mathrm{E}-04 \\
(4.91 \mathrm{E}-05) \\
\end{array}$ & \begin{tabular}{|c}
$3.05 \mathrm{E}-03$ \\
$(1.05 \mathrm{E}-04)$ \\
\end{tabular} & NA & $\begin{array}{c}2.47 \mathrm{E}-03 \\
(4.58 \mathrm{E}-04) \\
\end{array}$ & $\begin{array}{r}6.30 \mathrm{E}-03 \\
(5.98 \mathrm{E}-04) \\
\end{array}$ \\
\hline BNL-13 ${ }^{c}$ & $\begin{array}{c}2.27 \mathrm{E}-02 \\
(1.97 \mathrm{E}-04) \\
\end{array}$ & $\begin{array}{c}9.82 \mathrm{E}-03 \\
(6.61 \mathrm{E}-05) \\
\end{array}$ & NA & \begin{tabular}{|c|}
$2.43 \mathrm{E}-03$ \\
$(6.23 \mathrm{E}-04$ \\
\end{tabular} & $\begin{array}{r}5.40 \mathrm{E}-04 \\
(1.67 \mathrm{E}-04) \\
\end{array}$ & \begin{tabular}{|c|}
$4.31 \mathrm{E}-06$ \\
$(1.21 \mathrm{E}-05)$ \\
\end{tabular} & NA & $\begin{array}{c}2.53 \mathrm{E}-03 \\
(2.00 \mathrm{E}-03) \\
\end{array}$ & \begin{tabular}{|c|}
$9.34 \mathrm{E}-03$ \\
$(3.42 \mathrm{E}-04)$ \\
\end{tabular} \\
\hline BNL-7 & $\begin{array}{c}1.02 \mathrm{E}-02 \\
(2.37 \mathrm{E}-04)\end{array}$ & $\begin{array}{c}9.32 \mathrm{E}-03 \\
(2.17 \mathrm{E}-04) \\
\end{array}$ & NA & $\begin{array}{c}6.11 \mathrm{E}-03 \\
(1.73 \mathrm{E}-04)\end{array}$ & $\begin{array}{c}2.75 \mathrm{E}-03 \\
(4.18 \mathrm{E}-04) \\
\end{array}$ & $\begin{array}{c}4.36 \mathrm{E}-03 \\
(2.45 \mathrm{E}-05) \\
\end{array}$ & $\begin{array}{c}7.39 \mathrm{E}-03 \\
(9.06 \mathrm{E}-04) \\
\end{array}$ & $\begin{array}{c}3.96 \mathrm{E}-03 \\
(2.21 \mathrm{E}-03) \\
\end{array}$ & $\begin{array}{c}7.57 \mathrm{E}-03 \\
(1.15 \mathrm{E}-04) \\
\end{array}$ \\
\hline
\end{tabular}

a Leach data are the mean of 3 replicates; standard deviation shown in parenthesis.

b $\mathrm{NA}=$ not applicable (this metal not included in this formulation).

c Leach test conducted at $90^{\circ} \mathrm{C}$.

Table 2. $\quad$ PCT Leach Results for $\mathrm{Sn}-\mathrm{P}_{2} \mathrm{O}_{5}$ Glass-Composites.

\begin{tabular}{|c|c|c|c|c|c|c|c|}
\hline \multicolumn{8}{|c|}{ Normalized Leach Rate, $\mathrm{g} / \mathrm{m}^{2} / \mathrm{d}^{\mathrm{a}}$} \\
\hline & $\mathrm{Na}$ & $\mathrm{K}$ & $\mathrm{Fe}$ & $\mathrm{Al}$ & $\mathrm{Si}$ & $\mathrm{Sn}$ & $\mathrm{P}$ \\
\hline BNL-6 & $\begin{array}{c}3.93 \mathrm{E}-02 \\
(4.74 \mathrm{E}-03)\end{array}$ & $\mathrm{NA}^{\mathrm{b}}$ & $\begin{array}{c}1.99 \mathrm{E}-02 \\
(1.35 \mathrm{E}-03)\end{array}$ & $\begin{array}{c}7.33 \mathrm{E}-03 \\
(2.74 \mathrm{E}-04)\end{array}$ & $\mathrm{ND}^{\mathrm{c}}$ & $\begin{array}{c}6.78 \mathrm{E}-02 \\
(5.51 \mathrm{E}-03)\end{array}$ & $\begin{array}{c}8.63 \mathrm{E}-02 \\
(7.58 \mathrm{E}-03)\end{array}$ \\
\hline BNL-12 & $\mathrm{NA}$ & $\begin{array}{c}7.28 \mathrm{E}-02 \\
(9.09 \mathrm{E}-04)\end{array}$ & $\begin{array}{c}1.75 \mathrm{E}-02 \\
(8.23 \mathrm{E}-05)\end{array}$ & $\begin{array}{c}1.46 \mathrm{E}-02 \\
(3.19 \mathrm{E}-04)\end{array}$ & $\begin{array}{c}3.47 \mathrm{E}-03 \\
(5.66 \mathrm{E}-05)\end{array}$ & $\begin{array}{c}9.59 \mathrm{E}-02 \\
(1.24 \mathrm{E}-03)\end{array}$ & $\begin{array}{c}9.00 \mathrm{E}-02 \\
(2.02 \mathrm{E}-04)\end{array}$ \\
\hline
\end{tabular}

a Leach data are the mean of 3 replicates; standard deviation shown in parenthesis.

b NA = not applicable (this metal not included in this formulation).

c $\mathrm{ND}=$ not detected.

These results indicate that PCT leachability can be improved by up to a factor of 10 through proper selection of cation modifiers. Corrosion rate was reduced with increasing additions of Fe, as depicted in Figure 7. A similar trend may also exist for Al additions, although the effect is not so clear. Also of note was the fact that $90^{\circ} \mathrm{C}$ PCT leach results were virtually identical to room temperature tests. Direct comparison can be made, where sample BNL-13 was a $90^{\circ} \mathrm{C}$ test done using the same glass tested at room temperature as sample BNL-5. A metal-by-metal comparison for these tests is shown in Figure 8. The higher leach temperature yielded slight ly higher releases for 
alkali metals and phosphorous, and slightly lower releases for the other metals present. Sample BNL14 , another $90^{\circ} \mathrm{C}$ test, also produced low leach rates. However, as the formulation had been changed slightly from glasses BNL-10 and 11, no direct comparisons can be made. Although formulations have by no means been optimized, lowest leachability of the formulations tested was achieved in glasses containing sodium, as opposed to those containing potassium, or a combination of boron and sodium. Alkali and alkaline earth metals made up a significant fraction of these glasses, indicating their capacity to incorporate and retain significant TWRS salt contaminants.

Leach rates for tin-phosphate composites were only slightly higher than the best $\mathrm{Fe}_{2} \mathrm{O}_{3}-\mathrm{Al}_{2} \mathrm{O}_{3}$ $\mathrm{P}_{2} \mathrm{O}_{5}$ formulations. As only two formulations were tested, further development will be required to determine full potential of this matrix. XRD data on these composites is promising in that the glassy matrix appears to be retained. Chemical constituents in the dry surrogate waste, namely $\mathrm{Ca}, \mathrm{Al}$, and $\mathrm{Si}$, appear to be compatible with the low temperature glass.

PCT data for both iron-aluminum-phosphate and tin-phosphate matrices compare favorably with lead-iron-phosphate glasses and reference borosilicate high-level waste glasses. Sales and Boatner[14] quote leach rates of 0.73-1.25, 0.93-2.30, and 0.99-2.00 g/m²/d, for $\mathrm{Si}, \mathrm{B}$, and $\mathrm{Na}$, respectively, from borosilicate defense and commercial waste glasses. Comparable leach results from lead-iron-phosphate waste glasses were $<0.006,<0.001,<0.02$, and $<0.02 \mathrm{~g} / \mathrm{m}^{2} / \mathrm{d}$, for P, Fe, Al and $\mathrm{Na}$. These results are for leach tests done in distilled water $(\mathrm{pH} 7)$ at $90^{\circ} \mathrm{C}$ for 30 days.

\section{$\underline{\text { Conclusions }}$}

The need for alternative vitrification processes has been established based on incompatibility of reference borosilicate glass formulations with certain single-shell tank waste components. Further, lower temperature processes would be of particular interest so as to minimize loss of volatile hazardous metals during processing. While lead-iron phosphate glasses appear to offer advantages of reduced process temperature and improved chemical durability compared with borosilicate glass, their lead content is considerable (40-60 wt $\%$ ), posing the potential for excessive toxic releases from the glass matrix. Performance of hazardous and mixed waste forms will be largely based on TCLP (Toxicity Characteristic Leach Procedure), an acid leachability test not considered in the current literature. Preliminary lab results suggest that potentially significant problems exist with any leadbased glass system, silicate or phosphate, owing to the increased solubility of lead under acidic or basic conditions. Alternative phosphate glass formulations without lead have been reviewed and are favored for use as a host matrix.

Although there are many reports in the literature about phosphate glasses, the glasses were undesirable due to high processing temperatures $\left(>1100^{\circ} \mathrm{C}\right)$, poor chemical durability, or the incorporation of large amounts of lead (40-60 wt\%) in the matrix. A new low-temperature phosphate glass has been synthesized at $900^{\circ} \mathrm{C}$. This new formulation differs in the type and quantity of network modifiers added, resulting in a glass matrix with improved chemical durability and reduced melting temperatures. The formulation contains no lead or other hazardous components. The reduced processing temperature makes this glass suitable for the use of immobilization of low-level and mixed wastes, as well as for many alternative commercial glass products. 
A novel tin-phosphate glass composite was also synthesized at $450^{\circ} \mathrm{C}$. This matrix would be a good candidate for wastes containing low melting point or easily volatilized components which currently require secondary treatment under other vitrification scenarios. Further, as Tick's work on fluorophosphate glasses suggests, some solubility for halogens (fluoride, chloride, iodide) could be expected in these matrices.

Problematic TWRS components would appear to be treatable by low-temperature vitrification, although waste specific testing would be required to qualify and quantify compatibility and durability. Treatability would be improved over baseline borosilicate vitrification by virtue of the significantly reduced melting temperatures required to produce these glasses. Further, glasses investigated here contained a high percentage of alkali and alkaline earth metals, a limited demonstration of the capacity of these glasses to incorporate high levels of tank waste salts. Leachability of these new phosphate formulations appears comparable to lead-iron-phosphate glasses, and better than borosilicate nuclear waste glasses.

\section{References}

1. McElroy, J.L., W.J. Bjorklund, and W.F. Bonner, "Waste Vitrification: A Historical Perspective," PNL-SA-10261, CONF-820424-21, February 1982.

2. Grover, J.R., "HLW Solidification - Why We Chose Glass," AERE-R-9432, 1979.

3. Brouns, R.A., J.M. Perez, Jr., and B.M. Wise, "Selection of a Glass/Feed Composition for the West Valley Demonstration Project Slurry-Fed Melter," in Proceedings of American Nuclear Society International Topical Meeting, SPECTRUM '86, Vol. II, pp. 1107-1125.

4. Jantzen, C.M., "System Approach to Nuclear Waste Glass Development," Journal of Non-Crystalline Solids, Vol. 84, 1986, pp. 215-225.

5. Kalia, J., "Hanford Wast Vitrification Plant Technical Data Package," Revision 5, WHCSD-HWV-DP-001, 1991.

6. Wiemers, K.D., J.E. Mendel, A.A. Kruger, L.R. Bunnell, and G.B. Mellinger, "Preliminary Assessment of Candidate Immobilization Technologies for Retrieved Single-Shell Tank Wastes," PNL-7918, UC-721, January 1992.

7. Sales, B.C., "Phosphate Glasses," Materials Research Society Bulletin, Vol. XII 5, 1987, pp. 32-34.

8. Tuthill, E.J., G.G. Weth, L.C. Emma, G. Strickland, L.P. Hatch, R.F. Drager, and J.J. Fedelem, "Development of the Phosphate Glass Process for Ultimate Disposal of HighLevel Radioative Wastes," BNL 50130 (T-505), January 1968.

9. McElroy, J.L., et. al., "Evaluation of WSEP High Level Waste Solidification Processes," Waste Solidification Program Summary Report, Vol. 11, BNWL-1667, 1972. 
10. Van Geel, J., H. Eschrich, W. Heimerl, and P. Grziwa,"Solidification of High Level Liquid Wastes to Phosphate Glass-Metal Matrix Blocks," IAEA-SM-207/83, Vol. 1, pp. 341359, 1976.

11. Malow, G., "Testing and Evaluation of the Properties of Various Potential Materials for Immobilizing High Activity Waste," EUR Report, 1979.

12. Grambow, B., and W. Lutze, "Chemical Stability of a Phosphate Glass Under Hydrothermal Conditions," in Scientific Basis for Nuclear Waste Management II, Materials Research Society Symposium Proceedings, Vol. 2, 1980, pp. 109-116.

13. Sales, B.C., and L.A. Boatner, "Lead-Iron Phosphate Glass: A Stable Storage Medium for High-Level Nuclear Waste," Science, Vol. 226, October 1984, pp. 45-48.

14. Sales, B.C., and L.A. Boatner, "Physical and Chemical Characteristics of Lead-Iron Phosphate Nuclear Waste Glasses," Journal of Non-Crystalline Solids, Vol. 79, 1986, pp. 83-116.

15. Sales, B.C., M.M. Abraham, J.B. Bates, and L.A. Boatner, "Structural Properties of LeadIron Phosphate Glasses," Journal of Non-Crystalline Solids, Vol. 71, 1985, pp. 103-112.

16. Schiewer, E., L. Werner, L.A. Boatner, and B.C. Sales, "Characterization of Lead-Iron Phosphate Nuclear Waste Glasses," in Scientific Basis for Nuclear Waste Management IX, Materials Research Society Symposium Proceedings, Vol. 50, 1985, pp. 231-238.

17. Chick, L.A., L.R. Bunnell, D.M. Strachan, H.E. Kissinger, and F.N. Hodges, "Evaluation of Lead-Iron-Phosphate Glass as a High-Level Waste Form," PNL-5878, September 1986.

18. Day, D., Univ. of Missouri-Rolla.

19. Jantzen, C.M., "Investigation of Lead-Iron-Phosphate Glass for SRP (Savannah River Plant) Waste," DP-1729, October 1986.

20. Tick, P.A., "Water Durable Glasses with Ultra Low Melting Temperatures," Chemistry of Glasses, Vol. 26, No. 6, December 1984, pp 149-154.

21. Sales, B.C., L.A. Boatner, B.C. Chakoumakos, J.C. McCallum, and J.O. Ramey, "Structural Analysis of Amorphous Phosphates Using High Performance Liquid Chromatography," ORNL, CONF-931108-29, 1993.

22. Greaves, G.N., "Glass Structure and Diffusion," Science and Engineering Research Council (Daresbury Lab, England), DL/SCI/P-643E, 1989.

23. Day, D.E., and J.A. Wilder, Jr., "Chemically Durable Phosphate Glasses and a Method for Their Preparation; Patent Application," Department of Energy, Washington, DC, PATAPPL-6-447 847, 1982. 
24. Grossman, D.G., U.S. Patent 3, 732,087, 1973.

25. Adair, P.J., U.S. Patent 4,431,420, 1984.

26. Abe, Y., and H. Hosono, "Calcium Phosphate Glass-Ceramics for Biomedical and Biotechnological Applications," Asahi Glass Foundation for Industrial Technology, PB91167056, PC A16/MF A02, 1990.

27. Dixon, R.S., and E.L.J. Rosinger, Atomic Energy of Canada Ltd., AECL-7811, 1984.

28. Wilder, Jr., J.A., J.T. Healey, and B.C. Bunker, "Phosphate Glass Ceramics: Formation, Properties, and Applications," Sandia National Labs., CONF-810528-1, 1981.

29. Beall, G.H., and H.1. Rittler, U.S. Patent 4,314,909, 1982.

30. C.M. Jantzen, N.E. Bibler, D.C. Beam, W.G. Ramsey, and B.J. Waters, "Standard Test Methods for Determining Chemical Durability of Nuclear Waste Glasses: The Product Consistency Test (PCT)," Version 6.0, Westinghouse Savannah River Co., Aiken, SC, April, 1993. 


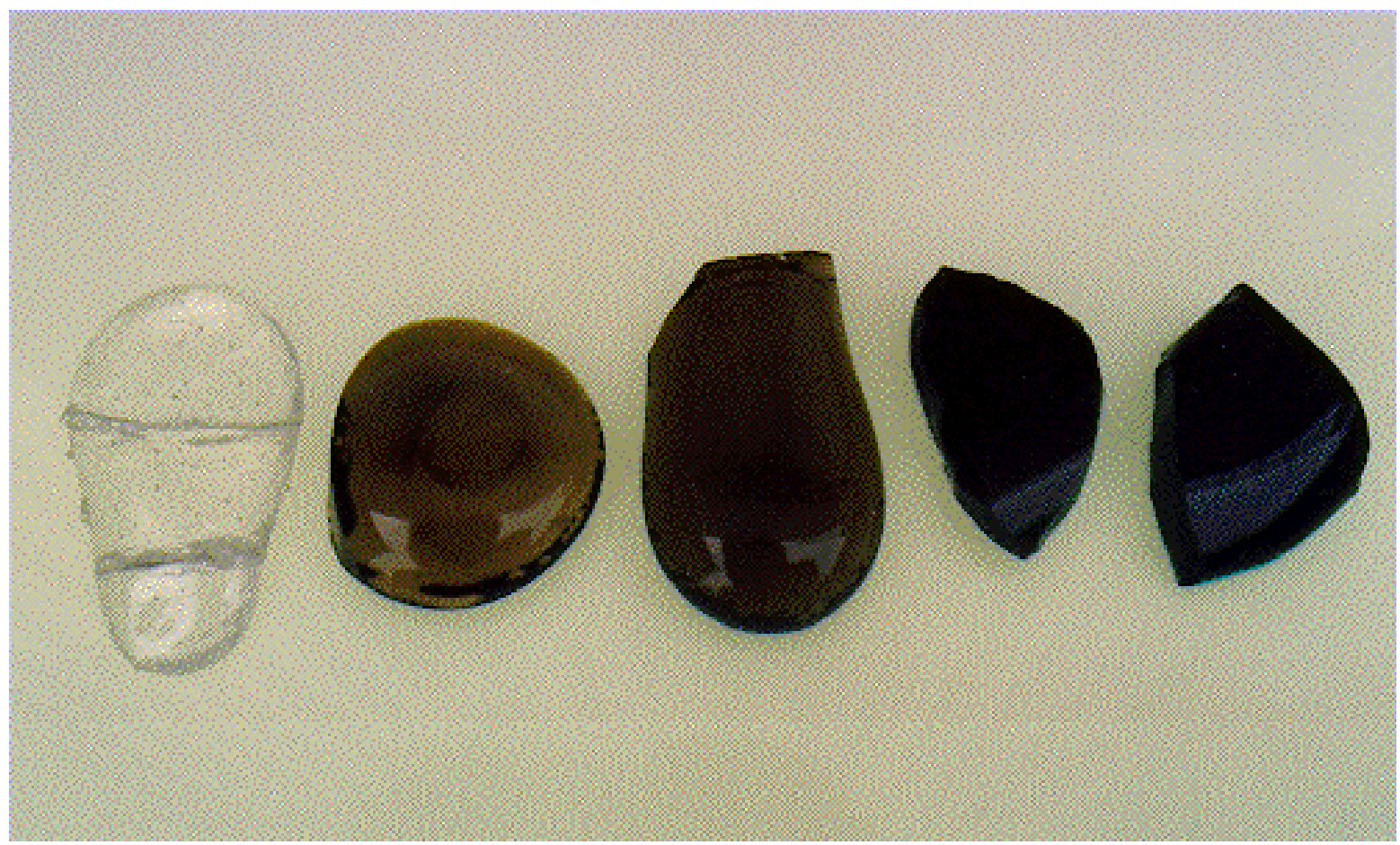

Figure 1. Photograph of Iron-Aluminum-Phosphate andTin-Phosphate Glasses

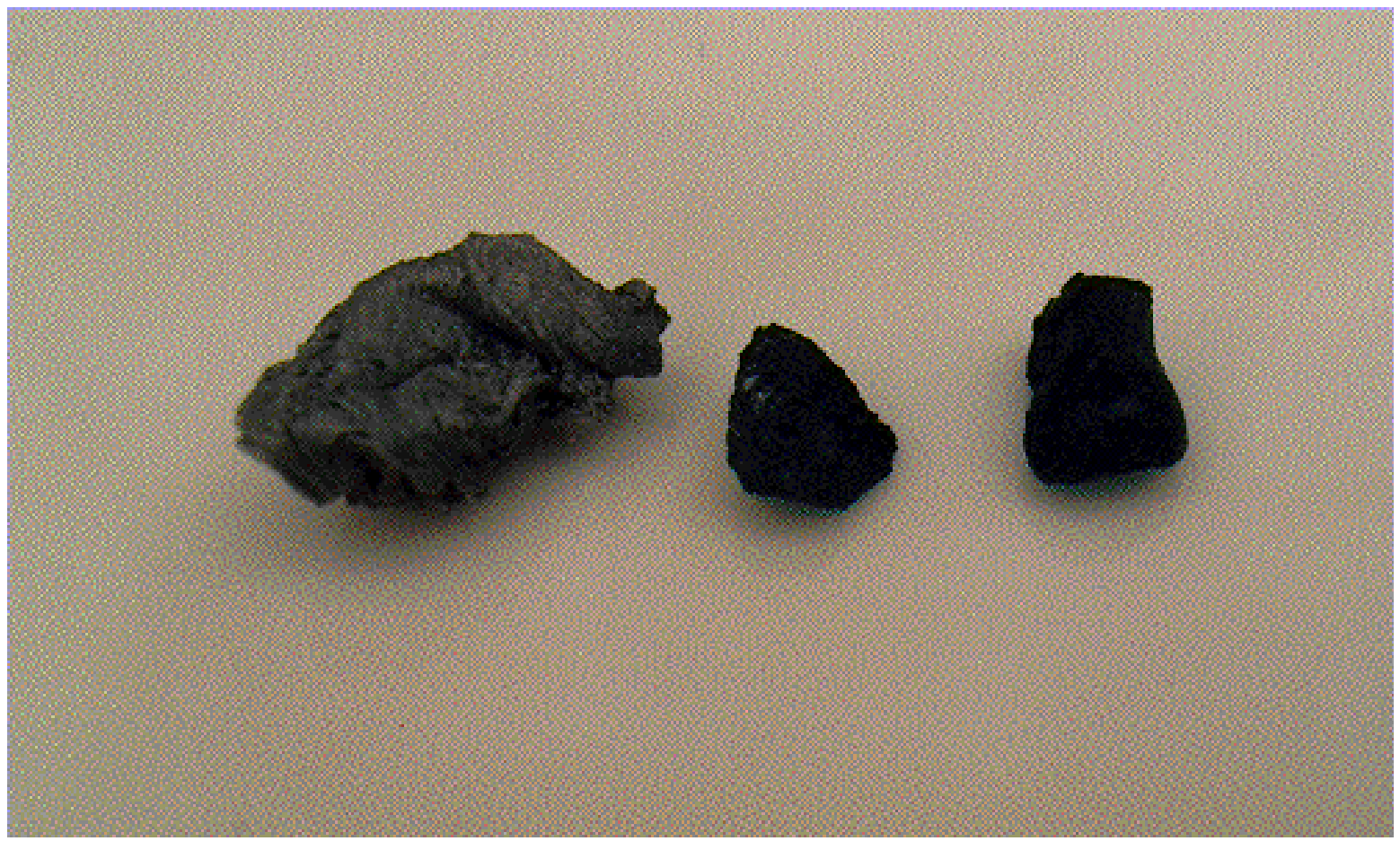

Figure 2. Photograph of Tin-Phosphate Glass-Composites. 


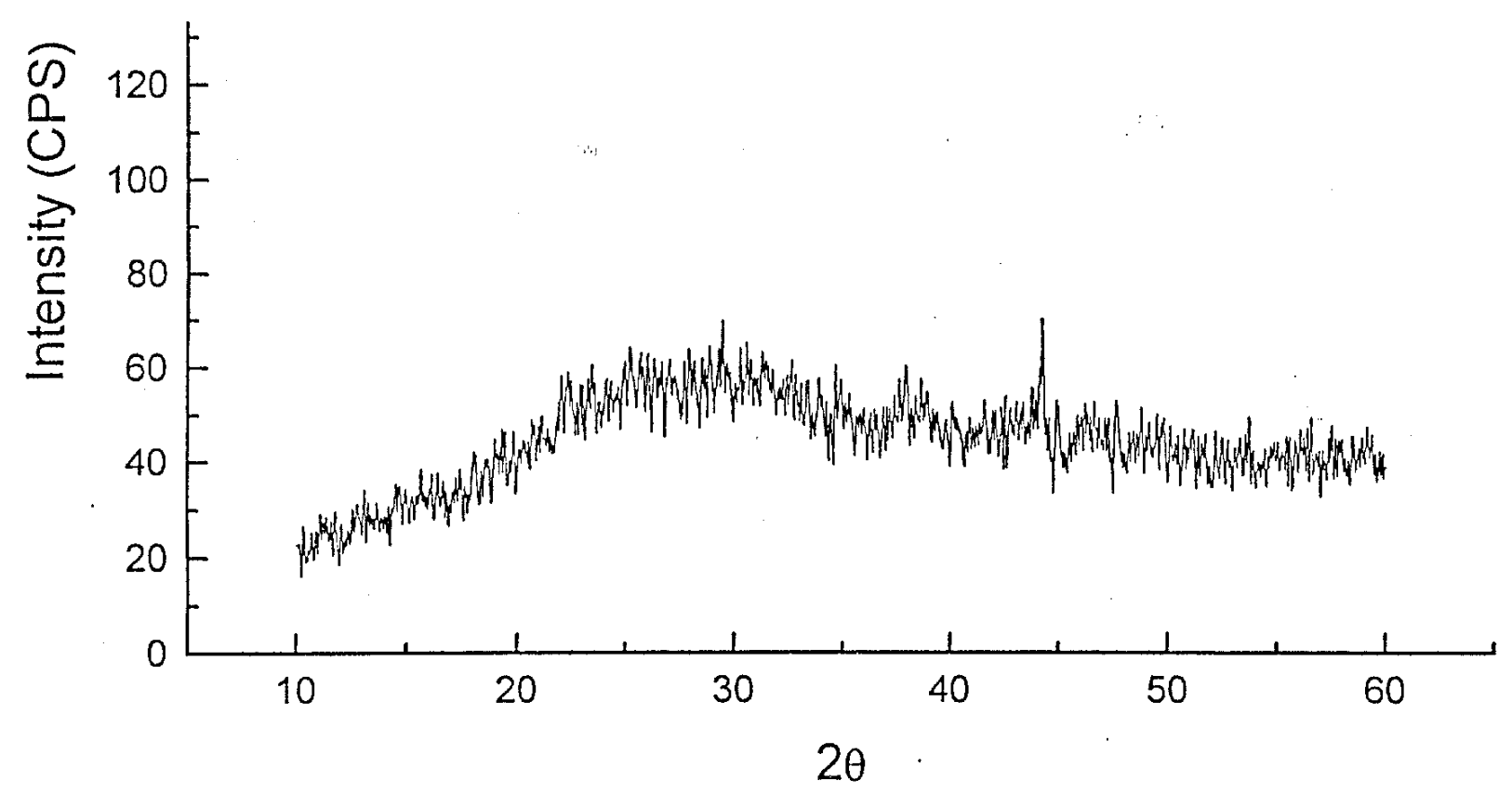

Figure 3. X-Ray Diffraction (XRD) Pattern for Iron-Aluminum-Phosphate Glass.

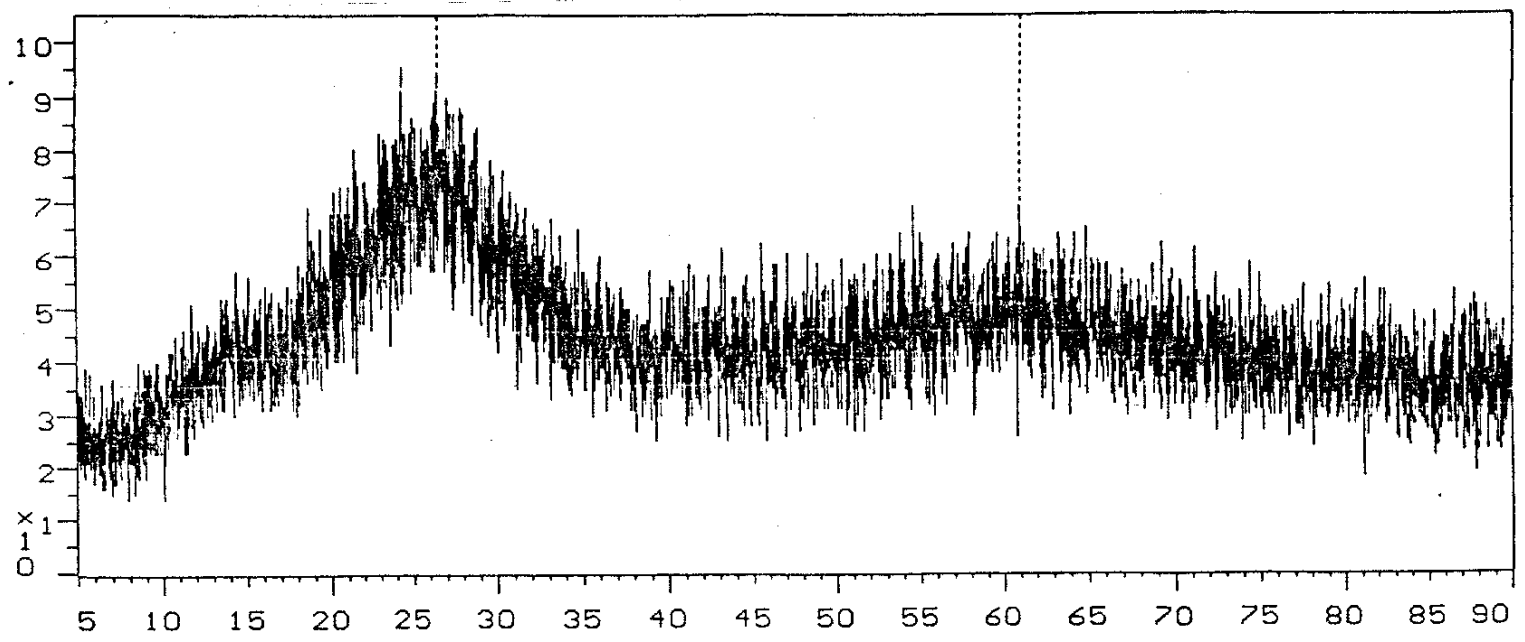

Figure 4. XRD Pattern for Tin-Phosphate Glass-Composite. 


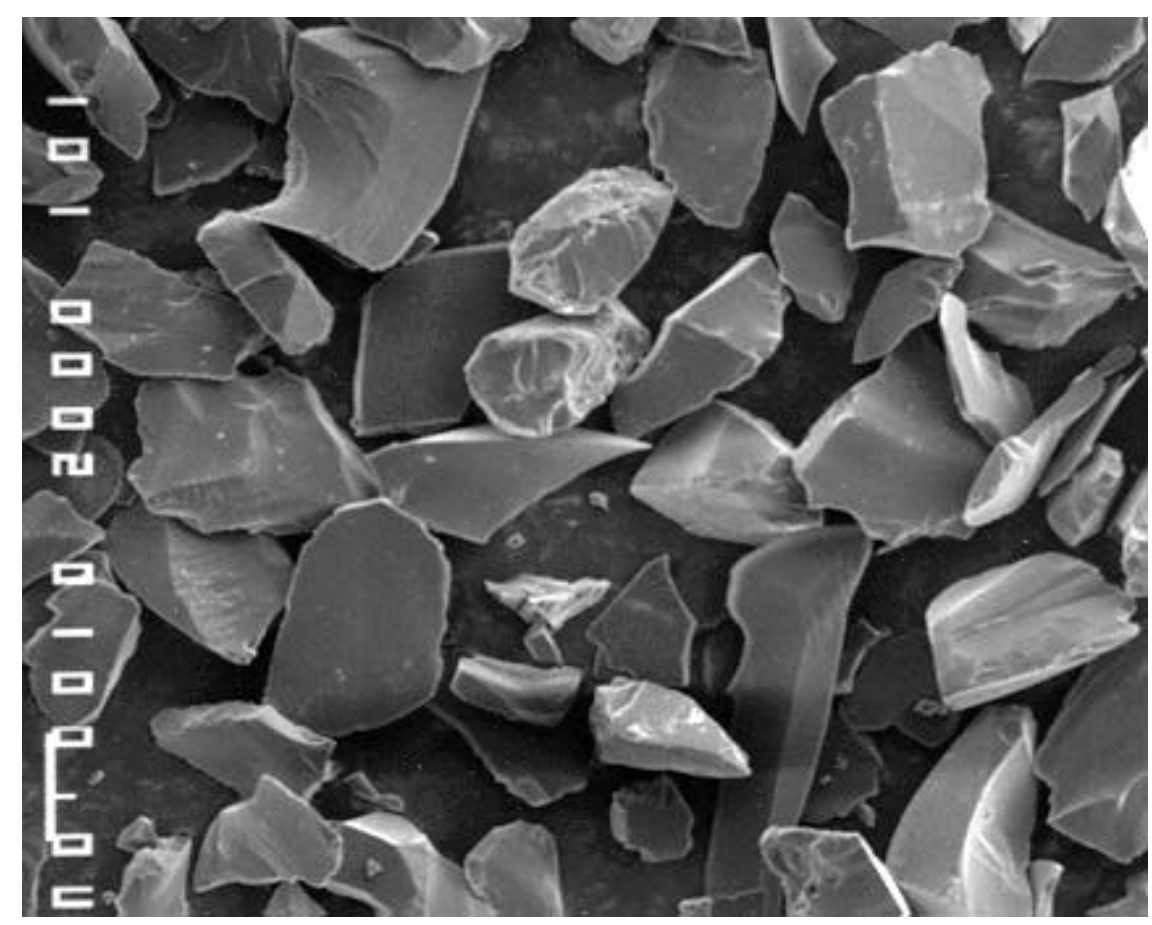

Figure 5. Scanning Electron Micrograph of Glass Powder Before Product Consistency Test (PCT) -100x Magnification.

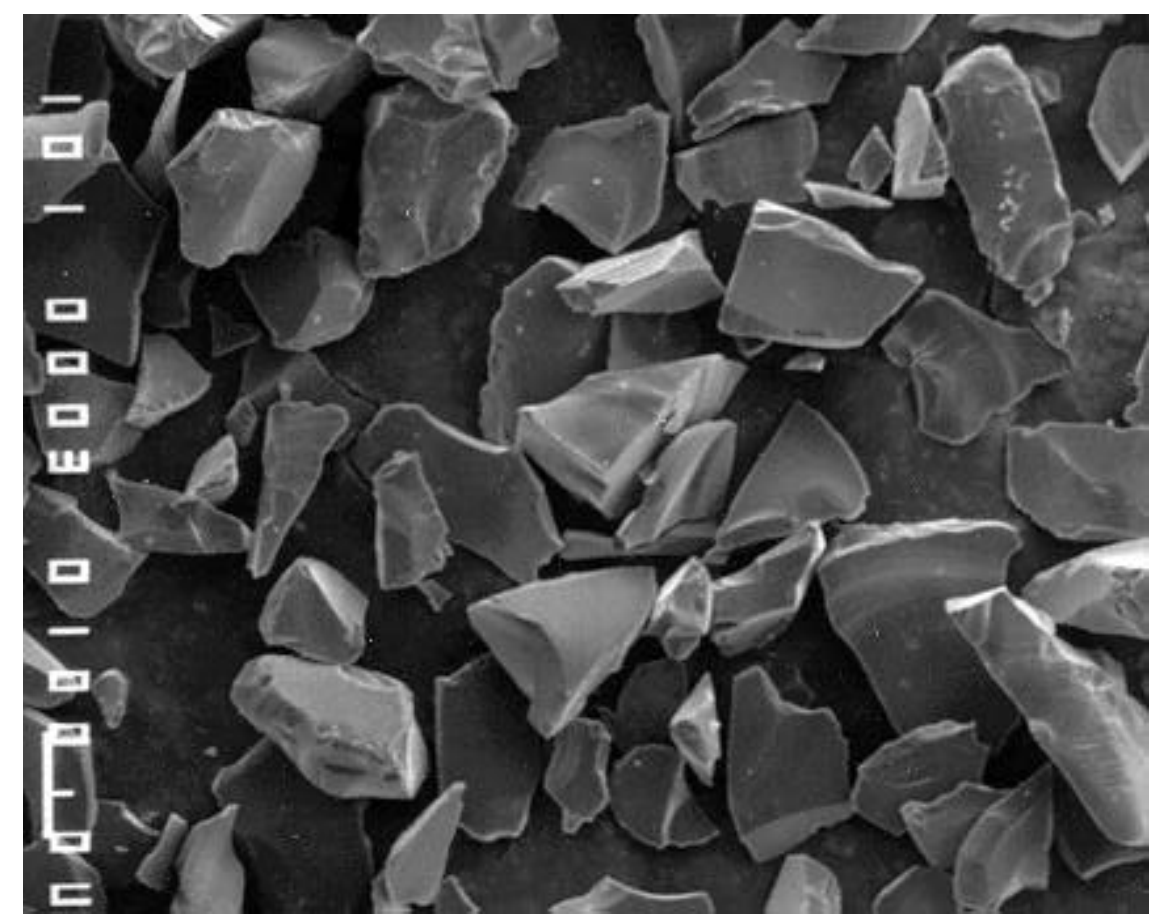

Figure 6. Scanning Electron Micrograph of Glass Powder After PCT -- 100x Magnification. 


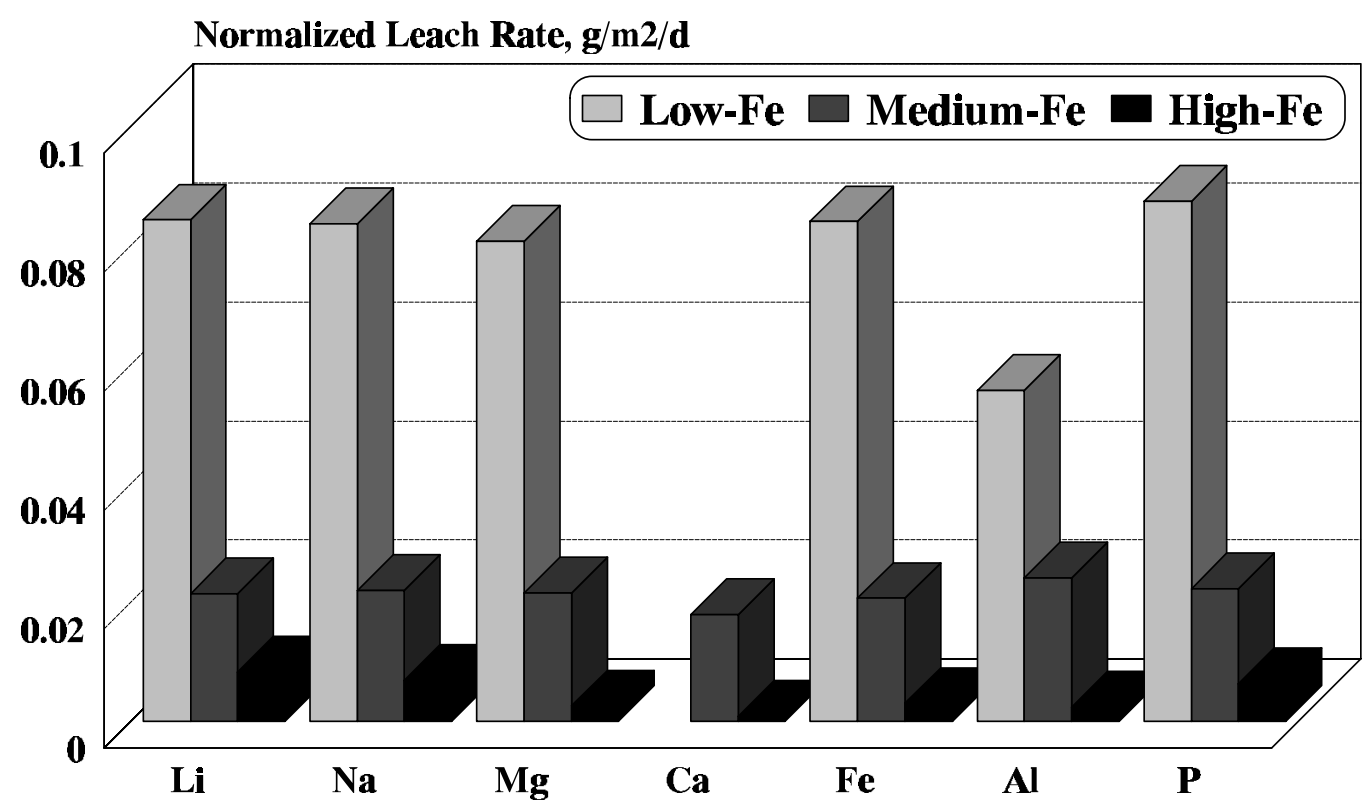

Figure 7. $\quad 25^{\circ} \mathrm{C}$ PCT Leach Results for Potassium-Free Iron-Aluminum-Phosphate Glasses.

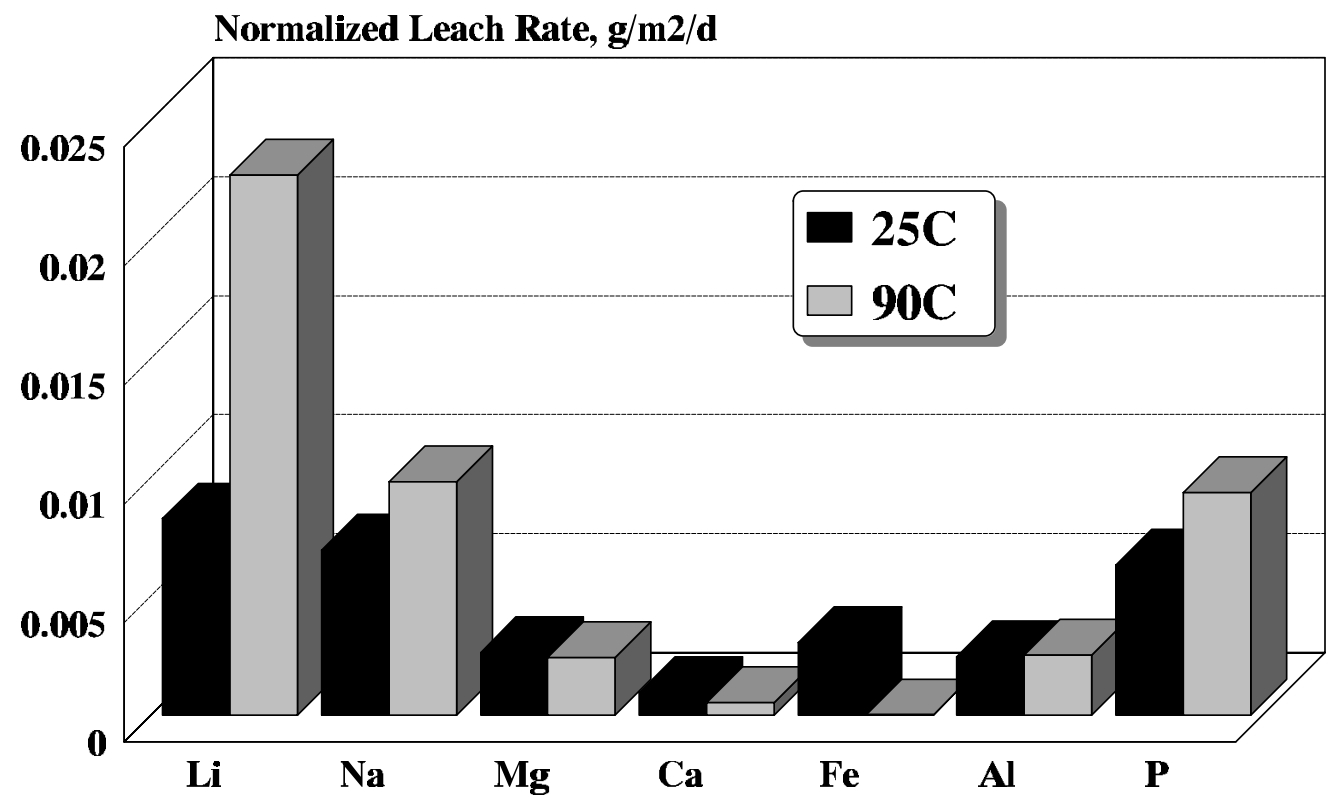

Figure 8. Comparison of $25^{\circ} \mathrm{C}$ and $90^{\circ} \mathrm{C}$ PCT Leach Resultsfor Iron-Aluminum-Phosphate Glass. 